\title{
Minangkabau Dance Form in the Context of ABS- SBK Values
}

\author{
Afifah Asriati \\ Seni Drama Tari dan Musik \\ Fakultas Bahasa dan Seni Universitas Negeri Padang \\ Padang, Indonesia \\ afifahasriati@yahoo.com
}

\begin{abstract}
This article aims to get the concept of Minangkabau dance forms in the context of ABS-SBK (Adaik Basandi Syarak, Syarak Basandi Kitabullah) values. Since now on, the Ninik Mamak (mother's brother and her man relatives), scholars and clever men in West Sumatra are working to develop ideas about the philosophy of ABS-SBK (custom derived from Islamic law, Islamic law derived from the Quran) in all aspects of life. How is it reflected in a dance? To answer this question, qualitative approach had been done by taking the case of six prominent traditional dances as Minangkabau popular dances. The data were collected through focus group discussion, observation and interviews. Through the analysis of triangulation, the credible data was expected to get. The results of the research show that the ideal dancers of Minangkabau dance are men with motion derived from martial arts and the traditional dress which is in accordance with Salingka nagari (custom in their community).
\end{abstract}

Keywords: Form, Minangkabau dance, ABS-SBK value

\section{INTRODUCTION}

Dance can be said as expressive body language that is expressing the culture of a community or community supporters. Minangkabau dance can also be said as a body language that expresses the cultural values of Minangkabau itself. Currently, penghulu (ninik mamak), alim ulama (men who know Islamic rules better) and cadiak pandai in Minangkabau are working to develop operational thinking about the philosophy of Adaik Basandi Syarak, Syarak Basandi kitabullah (ABS-SBK) that means custom derived from Islamic law, Islamic law derived from the Quran in various aspects of life. However, they also consider about how its existence in Minangkabau dance. Can this philosophy be conceptualized and applied on Minangkabau dance and how?

Related to the $A B S-S B K$ value in Minangkabau dance, the problem is exposed when there is a gap between the Minangkabau dance form and $A B S-S B K$. As in the dancers' element, the uniqueness of the original Minangkabau custom values in dancing is male dancers. Yet, the present state is somewhat shown contrast to the $A B S-S B K$ value, which now appears to be dominantly female rather than male dancers. It can also be seen from the show, the development is quite varied. Is the development of such a thing is in line or contrary to the value of the community?

Based on the Minangkabau dance phenomenon described above, it is necessary to conduct serious study in involving general dance concept (dance element) and Minangkabau concept in particular especially related to the values embraced by Minangkabau society philosophically. In summary, it can be formulated as how the form of Minangkabau dance is ideal or in line with the $A B S-S B K$ value? The conceptualization of Minangkabau dance is useful in relating the elements of Minangkabau dance with the value of $A B S-S B K$ philosophy. Because of the dance nowadays development in Minangkabau, as the phenomenon above describes, there may be a line, contradictory or in between (partially contradictory and partly in line) with the value of $A B S-S B K$ philosophy. This phenomenon becomes the fundamental importance of this research. How is the form (hypothetical) of Minangkabau dance when it is contextualized in the meaning of $A B S$-SBK value?

If the problem of this study can be answered with the availability of complete data, then hypothetically a Minangkabau dance which is worth $A B S-S B K$ will be formed. Due to the present condition of Minangkabau dance that still does not reflect the $A B S-S B K$ values embraced philosophically by Minangkabau society, the form of Minangkabau dance still indicates secularism, not in line with the value of $A B S-S B K$, even it is very contrary to the $A B S-S B K$ value. This is shown especially in a dance derived from the Hindu values such as Lukah Gilo dance (Desfiarni, 2004) that expresses and invites to be Syirik (believe in more than one God) when measured from the value of Minangkabau philosophy. Then there are also some prototypes that seem to have synergies with Syarak (Islamic) values, such as the Pasambahan dance which has the value of glorifying guests with motion and clothing reflecting the value of Syarak (Asriati, 2012). So the contribution of this research is to ensure that the values of Syarak $(A B S-S B K)$ are presented in the Minangkabau dance structure and form which vary in terms of the value expressed.

The results of this study are also useful for choreographers as a guide in the creation of Minangkabau dance in accordance with the ethnic identity of Minangkabau. Minangkabau dance choreographers are now more inclined to create dance that does not really consider the fundamental values of Minangkabau culture. Thus, the results of this study may also contribute to the development of instrument of Minangkabau dance.

Art as human nature is halal (Islamic term for "something that is allowed"), but the material put into it can be haram (Islamic term for "something that is forbid"). If the way and its implementation contradict what the Prophet has established, then 
it can be haram as Islam prohibits the dance performed by men and women together (Asriati, 2012; Gazalba, 1977: 53-54). More firmly, Gazalba (1977: 79) and Asriati (2015) argued that ethics or morals Islam that determines whether an art element is worth to be halal, makruh (Islamic term for "something that is a disliked or offensive act"), or haram. In this case there is a method formulated by Omar (1983: 57-58) that "music, sound art, and dance in Islam is mubah (permitted/neutral), as long as it is not accompanied by the haram things". Then, Toha formally makes the formulation as: 1) "when accompanied by things, that art may be haram, then the law becomes haram anyway. 2) "when it is accompanied by good things and is pleased with Allah, the law becomes sunah". So the haram of music, sound art, and dance is caused by other things, not because of its own substance (amrun 'aradhiyun la dzaitun).

In fact, art is the field of culture in Islam, as well as social, economic, political and others. Islamic art is intertwined in connection with Islamic culture. There are at least two differences between Islamic art and non-Islamic art; first is the motive or intention, and the second is the ethical value. God desires his servant's greeting and art is an element for the guidance of that greeting. The artist fulfils the pleasure in life. So, Islamic art is not an art for art. Islam wants that art is intended for God. When it is intended for God, it is moral. God tells the good and forbids the bad. Islam requires art that is run by Islamic morals (Sidi Gazalba, 1977: 53-54; Asriati, 2015).

In relation to the relationship of Islam with the special culture of art, Minangkabau art has been integrated in the philosophy of Adat Basandi Syarak and Syarak Basandi Kitabullah (ABS-SBK) which Naim (2004) and Asriati (2015) considered as identity of Minangkabau people. According to Mochtar Naim, the philosophical issue of the Minangkabau is neither longer on the level of the idea (concept), nor at the level of basic principles in everyday life, and even it is not the matter of principle in all aspects of life that has been perfected by Islam, but how $A B S-S B K$ is concretely realized by Minangkabau people in their social actions. As Mas'oed Abidin (2004) says that the current challenge is to rearrange the community with the value of ketauhidan (believe in one God/monotheism) and culture as the link tamaddun al Islami. According to Naim (2004: 50) ABS-SBK problem is also not a problem of history but it is a matter of maximizing its implementation in Minangkabau society systematically. He revealed that "Our next step now is to implement the $A B S-S B K$ teachings systematically and programmatically into various aspects of life". He asserted again that $A B S-S B K$ is not only a philosophy of life but also lighting (suluah bendang) for Minangkabau people in life. So, there needs to be a good and systemic program, not only to develop it conventionally. Actually, $A B S-S B K$ has been used as a philosophy in development in West Sumatra that becomes the foundation of philosophy to live together in community (Perda (local regulation) West Sumatra No. 9 year 2000 and No.27 year 2007).

Art development especially, including Minangkabau dance tradition, Muchtar Na'im (2004) names that there are absolute and relative concept of adat, also in between the two. 1) The substantive adat (adat nan sabana adat) is the absolute part, while 2) the part of the accidentia (adat istiadat dan adat nan diadatkan) beautifies itself that can be used better but when it is used, it should be adapted based on Quran rules.

Hence, the dance in Minangkabau culture is also included aesthetics. It can be used but it should be adapted to $A B S$-SBK value. At this level, it is implied that perhaps our dance contains a counter-value with Islamic values (Asriati, 2015). This matter apparently shown in Na'im (2004) which has also been cited by Asriati (2016) that the concept of $A B S$-SBK philosophy is actually the crystallization of the teachings of natural law in the form of the law which come form God (sunnatullah). In contact with Islam, the custom which is a patterned and cultural habit that must inevitably have to go through the process of purge of the elements polytheism (syirik), mystic (khurafat) and additional rituals that are not ordered to do (bid'ah) that is contrary to ketauhidan Islam. Since the final process of custom and custom synthesis is stipulated that adat must take into account syarak, the main reference of adat is syarak, while the reference of syarak is Kitabullah.

Further, from all the exposure to data and opinions above, it can be understood that the art of Minangkabau dance in truth must be in line, harmonious, appropriate and based on $A B S-S B K$ values that become Minangkabau ethnic philosophy. It means that Islamic religious values must be seen in all expressions of Minangkabau dance, at least not expressing a counter value with Islamic values.

\section{METHOD}

A qualitative approach was used for this study to collect data about the concept of Minangkabau dance in accordance with $A B S-S B K$ value with Focus Group Discussion technique, documentation, observation, and interview so that, a form or concept of Minangkabau dance based on $A B S-S B K$ can be drawn. The process of this research is described below.

\begin{tabular}{|c|c|}
$\begin{array}{l}\text { To find a hypothetic concept about } \\
\text { Minangkabau dance form based on } A B S-S B K \\
\text { context }\end{array}$ & $\rightarrow \begin{array}{c}\text { Methods } \\
\text { Dance elements } \\
\text { 1. Dancer } \\
\text { 2. Movement } \\
\text { 3. Costume }\end{array}$ \\
$\begin{array}{c}\text { Qualitative, FGD, documentation, } \\
\text { observation, deep interview. } \\
\text { Trilingual analysis \& Member } \\
\text { Check were used using Mills and } \\
\text { Harberman Model } \\
\text { RESULT }\end{array}$ \\
\hline
\end{tabular}

Figure 1. The process of the research 
To find out the results on how the concept of Minangkabau dance form in the ABS-SBK context, one nagari has been established in each district representing the original one (darek) and rantau (pasisie) regions. Darek region includes Padang Magek, Bayue, Taeh Baruah, while Pasisie area, III Koto Aur Malintang, Air Bangis and Southern Painan.

\section{FINDING AND DISCUSSION}

\section{A. Dancer criteria in ABS-SBK context}

Asriati (2015) explained the results of FGD in her study and found the criterion of dancers in accordance with $A B S$-SBK value of Minangkabau dance ideally it should be danced by men. Women have limitations for doing so. Meanwhile, it is allowed in certain dances to be performed by men and women, and some dances are still debated.

Based on the description of six dance samples on this research which are Mulo Pado dance, Piring Salapan dance, Piring Di Ateh Kaco dance, Indang dance, Sirompak dance and Kudo Rantak dance, it can be known and understood that the figure of Minangkabau dancer was originally dominated by men. This finding was in line with Hadi (2006) who stated that historically the concept of Minangkabau dance was performed by men only, whereas women were placed in neutral positions, as something sacred that should not be rendered in the middle of the crowd. The concept of such dancers was initiated from the cultural customs of the Minangkabau people with the matrilineal kinship system, which placed women as part of the people who should not be defective in the public eye. Minangkabau culture is supported by the influence of Islam which forbids women to show themselves outside non-muhrim person. In accordance with Wisran Hadi's point of view, Suryadi (1997) reflects Minangkabau history used to be only male who can be involved in art especially in dance. In line with that, Indra Utama (2007) also supports this opinion which emphasizes that even if there are women who are active as a doer of art and even then only a few, it may not be in the art of dance.

From the above three views, it can be said that since its first ancestors, artists, especially Minangkabau dance in the nagari was done by men and watched by men. Thus, there was no Minangkabau dance performed by women. Looking at this fact, it was actually started since ancient times that the special art of Minangkabau dance in accordance with the authentic and original customs, the dancers were male, and it was very compatible with the $A B S-S B K$ value.

This matter is really contrasted to today phenomenon that shows more female dancers do a dance, "unlike now, Piring dance tends to be danced by women" (Suryadi, 1997). The phenomenon of female dancers that existed in recent years is generally tolerated by adat values that are adaptive, flexible and responsive to developments that occur in the supporting community. Likewise the views of ulama, Islam allows women to become dancers by heeding the Islamic values that apply to Islamic women (Muslim) for example the dancers must qualify to cover the aurat (private body part) and not shake the hips. Although there are still scholars who disagree about this, but for reasons of emancipation, the development of the times, in addition there are also no scholars who opposed openly, then female dancers today can be tolerated. The Islamic requirement for female dancers is part of the value that is being solidified in society. Because there is a principle in Minangkabau adat that is Islam provides concept, custom to carry it out (Syarak mangato, adaik mamakai). This means that the value of religion is used as a real Minangkabau adat.

The findings formulated above has also been explained by previous researchers, such as the involvement of women in art as Sukmawati (2006) revealed that in reality women are not forbidden by adat and ulama to perform Dendang. There is a research which also concludes that women are not forbidden by indigenous and Islamic scholars to dance with restrictions imposed for a woman performing in public or stage (Astuti, 2004; Asriati, 2012). Although this finding is still controversial, because there are groups of Islamic scholars who argue that women should not dance. This means that the Minangkabau dance is still heeding the norms of adat and Islam as well.

In the next developments, Minangkabau dance performance is mixed between men and women. This statement was also mentioned by Suryadi, "Unlike now where Piring dance tends to be danced by women, who are sometimes still combined with male dancers (Suryadi, 1997).

FGD results on the dance used in this study showed that the phenomenon of mixing men and women in a dance show is still in debate and need to be reviewed again. It has also been revealed by Suryadi (1997) that, "If we look at Minangkabau history, it can be impressed that the cultural system and religious revolution (Padri War) has imposed limits on male-female relationships. In the field of dance, for example, there is hardly any duet element between men and women in Minangkabau dance, except perhaps in hybrid music like Gamaik which only exist in Padang. "So from the beginning there was no dance in Minangkabau whose dancers mixed between men and women. In the contrary, Gamaik in the city of Padang is not the original art of Minangkabau, but it is already acculturated with foreign culture (Hendrizal, 2013).

This prohibition is also mentioned by Gazalba (cited in Asriati, 2012: 79) Art as human nature is essentially halal, but the material put into it can be haram. If the way and its implementation are contrary to what the Rasul has established, it can be haram, as Islam prohibits the dances that done by men and women together. More firmly Sidi Gazalba argued that ethics or morals Islam that determines whether an element of art is worth to be halal, makruh or haram.

Thus, it can be inferred that the criteria of Minangkabau dance dancers in accordance with $A B S-S B K$ are (1) men, (2) women may be required to cover the aurat and they are not allowed to shake the hip, while (3) the mixed dance which involves 
men and women is allowed under the condition that they must not intersect between them is still in the debate, that means some of the scholars said it is allowed and others are still in doubts.

\section{B. Motion criteria as per ABS-SBK value}

Based on the results of the study from 6 samples involved, it has been found that Minangkabau dance movements in accordance with the context of $A B S-S B K$ value is the motion of martial arts or martial arts style. This finding is in line with what has been explained by Hadi (2006) which states that the concept of Minangkabau dance movement is "based on the motion of silat, thus it creates various dance forms in each nagari". Traditionally, the dance movement with the basis of this silat was formerly only done by men. However, seen from the phenomenon of today Minangkabau dance dancers are many of the women and the motion is the same as the motion of men. Hadi (2006) said that "the change of roles from men to women, then from male to transvestite. This is seen in the absence of different motion of men with the motion of women. All of these movements are uniform, as if it harasses human dignity itself ". Wisran Hadi's opinion is in accordance with the views of ulama scholars and traditional leaders in the nagari Padang Magek stating that "male dance movement is a movement that comes from the motion of silat" (Asriati, 2015).

As explained above, ideally Minangkabau dance is danced by male dancers along with pencak silat (martial art) movements. Supposed female dancers are also required, they must follow the following motion criteria: 1) the motion is not like a dance, 2) motion does not spit lust. 3) it does not include pornography, 4) its motion is not prominent (Asriati, 2015).

As the findings on the aspect of the dancers above, which states that women may dance to the criteria of motion that is not rocking hip and not indulgence, also has been mentioned by Asriati (2012). It has also been found in the dance created by Huriah Adam whose dance movement is in accordance with ABS-SBK because the dance movement for women is neither erotic nor sensual; dance movement is not done excessively beyond the ethical and aesthetic limitations of Minangkabau culture based on the religion and adat values (Utama, 2007).

If it is viewed from the value of Islam, Yunus (2013) argued that "what is being presented in the arts from the perspective of Islam is a collection of values mau'izhah (beautiful teaching), wisdom (full of wisdom and or local wisdom), and irsyadah (giving way to the right path). These values are the presentation of the main value of the mission of Islam that is the improvement of al-akhlaq al-karimah (good behaviour)", the mean of art is including dance should be able to form a good moral (al-akhlaq al-karimah). Therefore, the art of dance should contain messages of a beautiful nature (mau'izhah), local wisdom (wisdom) and give the right path (irsyadah). These values according to Yunus (2013) should be appreciated to become the main point in displaying the four values that become good behaviour in Minangkabau society that is the appearance of value; polite, kind mind, and a good language. Theoretically, Yulizar conceptualized that "These four values are applied in an application that gives control to the creativity and show ... the arts in the form of three values with the $3 \mathrm{ka}$ memotechnique namely (1) ethics, (2) erotica and (3) aesthetics". Ethics (akhlaq karimah-a kind behaviour) says Yunus (2013) it can and should function to control the aesthetic and erotic offer that restricts form of art fan li fan (l'art for l'art for art only) whose beauty is easy to present porn serving that stimulates lust".

Similar to Yunus, for Wisran (in Yunus, 2013): Islamic art or Islamic art like the $A B S$-SBK philosophy of Minangkabau society, "is not only a religious symbol but must have clarity of essence and substance. He criticizes the non-humanely artistic tendencies - exploiting and selling naked things, do not rooted in their own culture, and not at home and imaginations that is apposed to aqidah".

Such artistic performances according to Wisran "should have been strictly selected, put it back to the cultural roots of a natural nation and full of religiosity, which in other languages towards the Theo-humanist literary arts (carrying the human aspect without forgetting the conscience of the God)." Wisran Hadi stated, "The kind of art that should be developed such as dance, which is civilized and educate, he added, avoid the inhumanely interpretation that he calls like selling the type of dance which the dancers wear less-dressed in the performances and exploitation of tribal estranged like Mentawai-Sumbar .... Looks like dance from this area (West Sumatra) solace, it is difference like Bali dancing which dances are interpreted as worship, Minangkabau dance should be so".

In short, Wisran views that the idea of dance or art in Minangkabau is related to how Minangkabau dance can be conceptualized as a means of worship for the Islamic Minangkabau community, such as Balinese dance that becomes a means of worship for its people, instead of using and imitating other culture that is not based on cultural and the religion values of Minangkabau people. Perhaps, such dance (charged local wisdom) is needed and sought after by foreign tourists. They do not seek a dance that they have enjoyed so far in their countries, especially in Europe. This is supported by the customary norms that regulate the unfavourable matters for women which in term Minangkabau "sumbang" or oddly contained in "sumbang duo baleh" one of which mentioned "sumbang duduak, sumbang tagak, sumbang bajalan ..." This means that Minangkabau dance dancers should avoid the motion of pelvic hips that promote lust.

When it comes to the motion performed that contain magic, which is encountered in Piring Di Atas Kaca dance in Bayue Maninjau and Sirompak dance in Taeh Lima Puluh Kota, which according toAsriati (2015) in view of their Ulama in those two nagari it also found the existence of magic, and by Kadir (quoted Soedarsono, 2002: 39-43) in the title of his thesis "The Mystery Behind Piring Di Atas Kaca dance in Andaleh Village of West Sumatra" which states that the dance performed is always led by a 
man called Kulipah, someone who has responsible for the performance of the show. This is similar to what the researchers found in Piring Di Atas Kaca dance in Bayue and Sirompak in Taeh Lima Puluh Kota. Ernida Kadir revealed that the appearance of Kulipah who recited the mantras during the show was due to the remains of animism that still existed there. Because before the entry of Islam to Minangkabau, Hindu-Buddhist has first influenced the original art of Minangkabau people. Finally, this matter formed the dance that shows the irrational and mystical attractiveness. If this is mystique, definitely, the motion is not in line or against the $A B S-S B K$ value. Hadi (2006) says "Dances that use spells, which can harm aqidah should be shunned, if necessary neglected".

Magic is certainly very close to syirik. The dance which involves syirik in its movement as opposed to $A B S-S B K$ is needed not to be performed anymore. As Naim (2004) states the concept of $A B S$-SBK philosophy is actually the crystallization of the teachings of natural law in the form of sunnatullah. ... do contact with Islam, custom which is a patterned and cultural habit that must inevitably have to go through the process of purge of the elements of polytheism (syirik), khurafat and bid'ah that contradicts to the Islamic ketauhidan.

\section{Fashion Criteria as per ABS-SBK Rating}

Asriati (2015) concluded that the clothing used by male dancers consisting of clothes, pants, turban and sisamping. While the shape of the design or the use depends on the custom of each nagari called adaik salingka nagari. An example of how the use of a turban, in Bayue turban is called as deta tanduak kuciang, whereas in Padang Magek it is called deta pucuak rabuang.

Asriati $(2011,2012)$ also found that the choreographers of Minangkabau dance in general use custom clothing in its dance fashion and it is better to use a cloth that has been modified to criteria that indicates to cover the aurat. This is in accordance with Islamic teachings the clothing criteria for Muslim women as it is stated in; Sura Al-Ahzab verse 59: "O Prophet! Tell your wives, your daughters, and the women of the believers to bring down over themselves (part) of their outer garments ..." That means female dancers must cover their private parts of body. Likewise in custom, there is a norm of ethics in Minangkabau custom called sumbang for women that is for example dressed like men, wearing tight and transparent clothes, showing aurat (Hakimy, 1988: 108-111 in Astuti 2004: 72 ). "And tell the believing women to reduce (some) of their vision and guard their private parts and not expose their adornment except that which (necessarily) appears thereof and to wrap (a portion of) their headcovers over their chests ..." (Sura An-Nur verse 31).

As it is mentioned above that basically Minangkabau dancers are male, but if women are also needed to dance, hence they must follow certain criteria that are, 1) cover aurat, 2) do not show off clothes, 3) men dress men dressed and women dress women dressed (Asriati, 2015).

Based on the criteria of Minangkabau dance form from the aspect of the dancers, the motion or movement, and the clothing described above, Hadi (2006) remains in his stance that "Do not accept forms of dance that only indulge sex, both in the theme, movement and dress also in its demonstration". It was also revealed in the results of this study.

\section{CONCLUSION AND RECOMMENDATION}

The criteria of Minangkabau dancers in line to the $A B S-S B K$ value should be male. Women are tolerated on condition that they cover the nakedness and not shake the hips. While the dances that mix male and female dancers is also under condition to not intersect each other, furthermore it is still in debate. It means that some scholars stated that it is allowed, some are still doubts, and some even forbid. Meanwhile, the criteria of Minangkabau dance movement should be danced by male dancers with pencak silat movements. If women are also needed to dance, hence they must follow certain criteria that are: (1) the movement is not like a dance, (2) the movement does not spit lust. (3) it does not promote pornography, (4) the movement is not prominent. The clothing criteria according to the concept of $A B S-S B K$ value for male dancers consisting of clothes, pants, turban and sisamping. While the shape of the design or its use depends on the custom of each nagari called adaik salingka nagari. In essence, Minangkabau dancers are male, but if women are needed to be involved then the clothes used also have certain criteria that is, 1) cover aurat, 2) do not show off clothes, 3) male wearing men's dress and female wearing women's dress.

\section{References}

Abidin, M. (2004). Implementasi Adat Basandi Syarak, Syarak Basandi Kitabullah. Padang: Pusat Pengkajian Islam dan Minangkabau (PPIM).

Asriati, A. (2011). Degradasi Makna Simbolik Busana Adat Minangkabau (Studi tentang Kasus-kasus Busana Adat Dalam Tari dan Penyambutan Tamu), Humanus, X (1).

Asriati, A. (2012). Tari Pasambahan dan Falsafah Minang: Dalam Perspektif Alim Ulama Kota Padang. Humanus, XI (2). 145-159.

Asriati, A. (2015). The Figure of Minangkabau Dancers an Entity of Minang dancer based on the Value ABS-SBK. Prooseding International Seminar Languages and Arts (ISLA)-4 Padang: FBS Universitas Negeri Padang.

Asriati, A. (2016). Pandangan Pemangku Adat terhadap Tari Pasambahan di Kota Padang. Humanus. XV (1). 1-12.

Asriati, A, Ahmad K., Desfiarni. (2015). Konseptualisasi Bentuk Tari Minangkabau dalam Konteks Nilai ABS-SBK. Laporan Penelitian Fundamental. Padang: Universitas Negeri Padang.

Astuti, F. (2004). Perempuan dalam Seni Pertunjukan Minangkabau. Jogjakarta: Kalika.

Gazalba, S. (1977). Pandangan Islam Tentang Kesenian. Kuala Lumpur: Pustaka Antara. 
Hadi, W. (2006). "Dunia Hiburan Tanpa Perempuan: Kekuatan dan Ciri Utama Tari Minang”. Makalah untuk Diskusi Seni dalam kegiatan Contemporary Dance Festival (MCDF) dan acara HUT Kota Padangpanjang ke 216, Dies Natalis STSI ke 40 dan Mengenang wafatnya Hoeriyah Adam ke 35, 12 Desember 2006 di STSI Padang Panjang.

Hendrizal. (2013). Studi Analisis: Nilai-nilai Estetika Lokal dalam Musik Gamat. Ekspresi. 15(1).

Na'im, M. (2004). Dengan ABS-SBK (Adaik Basandi Syarak, Syarak Basandi Kitabullah) Kembali ke Jati Diri. Dalam buku Minangkabau yang Resah (ed, Latief, et al). Bandung: CV. Lubuk Agung.

Omar, T. Y. (1983). Hukum Seni Musik, Seni Suara, dan Seni Tari dalam Islam. Jakarta: Penerbit Widjaya.

Utama, I. (2007). Kesenian Minangkabau Masa Kini: Antara Tradisional dan Gagasan Modern. A Paper presented in $2^{\text {nd }}$ International Conference on Southeast Asia Department of Southeast Asian Studies, Faculty of Art and Social Sciences. Universiti Malaya, Kuala Kuala Lumpur, Malaysia 3 - 4 December 2007.

Soedarsono. (2002). Seni Pertunjukan Indonesia: Di Era Globalisasi. Edisi ketiga. Yogyakarta: Gadjah Mada University Press.

Sukmawati, N. (2006). Ratapan Perempuan Minangkabau Dalam Pertunjukan Bagurau: Gambaran Perubahan Sosial Minangkabau. Padang: Andalas University Press.

Suryadi. (1997). Opleiding Talen en Culturen van Zuid-en Zuidoost-Azië, Universiteit Leiden. dalam Niadilova. Minang Saisuak \#104 - Tari Piring di Sungai Pua. http://niadilova.blogdetik.com/index.php/archives/997 dilayari 9 Mei 2015.

Yunus, Y. (2013). Konsep dan Perubahan Dalam Seni Tradisional Minangkabau. http://yuyucenter.blogspot.com/2013/11/konsep-dan-perubahan-dalam-seni.html. Retrieved on Mei $30^{\text {th }} 2015$. 